\title{
WAKTU HENTI CHLORAMPHENICOL PADA LOBSTER (Cherax quadricarinatus) AIR TAWAR
}

\section{Withdrawal Time Chloramphenicol in Fresh Water Lobster (Cherax quadricarinatus)}

\author{
Miftahul Jannah ${ }^{1}$, Hari Suprapto ${ }^{2}$ dan dan Kusnoto ${ }^{3}$ \\ ${ }^{1}$ Program Studi Budidaya Perairan, Fakultas Perikanan dan Kelautan, Universitas Airlangga, Surabaya \\ ${ }^{2}$ Departemen Manajemen Kesehatan Ikan dan Budidaya Perairan, Fakultas Perikanan dan Kelautan, Universitas \\ Airlangga, Surabaya \\ ${ }^{3}$ Fakultas Kedokteran Hewan, Universitas Airlangga, Surabaya \\ miftahul.jannah-2015@fpk.unair.ac.id
}

\begin{abstract}
Abstrak
Permintaan yang tinggi oleh konsumen terhadap produk perikanan terutama lobster (Cherax quadricarinatus) air tawar dari tahun ketahun memacu perkembangan industri budidaya lobster yang sangat pesat. Namun dalam proses budidaya tersebut banyak sekali kendala yang muncul. Salah satu kendala yang umum dihadapi dalam budidaya ikan adalah adanya serangan penyakit yang disebabkan oleh bakteri. Beberapa strategi pencegahan penyakit yang telah diaplikasikan dalam budidaya lobster, salah satunya menggunakan antibiotik. Salah satu antibiotik yang sering digunakan pembudidaya adalah Chloramphenicol. Pada Lobster, penggunaan Chloramphenicol dengan dosis tinggi akan menyebabkan resistensi terhadap bakteri patogen.

Pelaksanaan penelitian di Laboratorium Pendidikan Perikanan, Fakultas Perikanan dan Kelautan, Universitas Airlangga dan Balai Karantina Ikan Pengendalian Mutu dan Keamana Hasil Perikanan Kelas I Surabaya II. Penelitian ini berlangsung pada bulan November 2013 sampai bulan Januari 2014. Tujuan penelitian ini adalah untuk mengetahui lama waktu henti obat yang diperlukanagar residu antibiotik Chloramphenicol yang terdapat pada Lobster (Cherax quadricarinatus) air tawar menurun hingga batas aman untuk dikonsumsi. Lobster yang diberi pakan dengan campuran chloramphenicol dengan dosis $2 \mathrm{~g} / \mathrm{kg}$ pakan terdeteksi residu Chloramphenicol tertinggi sebanyak 31,962 ppb pada minggu pertama dan terjadi penurunan residu menjadi 3.53 ppb selama delapan minggu.
\end{abstract}

Kata Kunci : Waktu Henti, Lobster (Cherax quadricarinatus) Air Tawar dan Chloramphenicol.

Abstract

The high demand for consumers on fishery products especially of Fresh Water Lobster (Cherax quadricarinatus) from year to year has made the development of Lobsters cultivation industry which is very fast. But in the process of cultivation was widely all obstacles appeared. One of the difficulties faced in the cultivation of fish common is the presence of attack of a disease caused by the bacterium. Some prevention strategies of disease that has been applied in the cultivation of lobsters, one of them is the use of antibiotics. One of an antibiotic that is often used by cultivator is Chloramphenicol. In the Lobster, the use of Chloramphenicol with high doses will cause resistance to pathogenic bacteria.

The research was held in Fisheries educational laboratory, Faculty of Fisheries and marine, Airlangga University and in Fish Quarantine Quality Control and Safety of Fishery Centre Class I Surabaya II Tanjung Perak. The research was conducted in November 2013 and was completed in January 2014. The purpose of this research was to determine the amount decrease of chloramphenicol residues against withdrawl time in Fresh Water Lobsters (Cherax quadricarinatus) until limit safe for consumption. This research using UPLC (Ultra Performance Liquid Chromatografi). Lobster feed with a mixture of Chloramphenicol with a dose of $2 \mathrm{~g} / \mathrm{kg}$ of food was detected residue of Chloramphenicol highest as many as $31,962 \mathrm{ppb}$ on the first week and decreased to $3.53 \mathrm{ppb}$ for eight weeks. Keywords : Withdrawal Time, Fresh Water and Chloramphenicol. 


\section{PENDAHULUAN}

Penggunaan antibiotik atau obatobatan dalam menangani masalah kesehatan dalam budidaya lobster air tawar dapat menyebabkan terjadinya residu dalam daging. Menurut Adam (2002) resi$\mathrm{du}$ antibiotik terjadi akibat penggunaan antibiotik yang tidak memperhatikan waktu henti obat, penggunaan antibiotik yang melebihi dosis yang dianjurkan, serta penggunaan atibiotika sebagai feed additive dalam pakan hewan.

Pada tahun 2004-2005 kebutuhan pasar di Eropa dan Asia Tenggara akan lobster air tawar dapat mencapai 1.589 ton (Lukito dan Surip, 2007). Hal tersebut akan terus meningkat dari tahun ke tahun namun produksinya belum dapat mengimbangi permintaan tersebut. Tingginya permintaan konsumen terhadap produk perikanan terutama lobster (Cherax quadricarinatus) air tawar dari tahun ketahun memacu perkembangan industri budidaya lobster yang sangat pesat. Namun dalam proses budidaya tersebut banyak sekali kendala yang muncul. Salah satu kendala yang umum dihadapi dalam budidaya ikan adalah adanya serangan penyakit yang disebabkan oleh bakteri. Beberapa strategi pencegahan penyakit yang telah diaplikasikan dalam budidaya lobster, salah satunya menggunakan antibiotik.

Salah satu antibiotik yang sering digunakan pembudidaya adalah Chloramphenicol. Chloramphenicol sejak lama digunakan dalam industri peternakan dan perikanan sebagai feed additive dalam pakan yang bersifat sebagai obat dalam penanganan beberapa penyakit yang menjangkit ikan, residu yang ditinggalkan dalam tubuh ikan yang dikonsumsi manusia dapat menyebabkan alergi, toksisitas bahkan kematian pada penderita anemia yang bisa berlanjut ke leukemia.

Penggunaan antibiotik umumnya digunakan untuk menanggulangi penyakit yang disebabkan oleh bakteri (Tendencia dan de La Pena, 2001). Chloramphenicol merupakan antibiotik dengan spektrum kegunaan yang cukup luas dalam membunuh bakteri. Chloramphenicol dahulu digunakan dalam pengobatan untuk hewan dan manusia tetapi karena adanya laporan bahwa Chloramphenicol menimbulkan penyakit anemia aplastik bagi manusia sehigga sejak tahun 1994 di Uni Eropa penggunaan Chloramphenicol tidak diijinkan (Akhmadi, 2006). Adanya larangan penggunaan senyawa ini dikarenakan sifatnya yang tidak mudah diurai oleh tubuh.

Asupan Chloramphenicol dalam waktu lama akan meninggalkan residu berlebih dalam tubuh dan ini tentunya akan bersifat toksik bagi tubuh manusia. Munculnya residu pada bahan pangan asal hewan terkait dengan tidak diperhatikannya lama waktu henti obat (withdrawal time) dan setiap obat memiliki masa waktu henti obat yang berbeda-beda. Adanya residu Chloramphenicol dapat menimbulkan dampak buruk bagi kesehatan.

\section{Metode Penelitian}

Metode yang digunakan dalam penelitian ini adalah metode eksperimental. Penelitian ini terdiri dari dua perlakuan yaitu kontrol dan Chloramphenicol. Penelitian ini dilakukan pengulangan sebanyak tiga kali. Perlakuan Chloramphenicol yang diberikan berupa perbedaan waktu pengecekan residu dengan rincian sebagai berikut.

1) T0 : merupakan kontrol, berisi lobster yang diberi pakan berupa pellet tanpa campuran Chloramphenicol.

2) T1 : Lobster diberi pakan berupa pellet dengan campuran Chloramphenicol dengan dosis $2 \mathrm{~g} / \mathrm{kg}$ pakan selama seminggu kemudian dilakukan pengecekan residu.

3) T2 : Lobster diberi pakan berupa pellet dengan campuran Chloramphenicol dengan dosis $2 \mathrm{~g} / \mathrm{kg}$ pakan selama seminggu, setelah itu diberi pakan pellet tanpa campuran Chloramphenicol kemudian dilakukan penge- 
cekan residu setelah 4 minggu dari awal pemberian pakan.

4) T3 : Lobster diberi pakan berupa pellet dengan campuran Chloramphenicol dengan dosis $2 \mathrm{~g} / \mathrm{kg}$ pakan selama seminggu, setelah itu diberi pakan pellet tanpa campuran Chloramphenicol kemudian dilakukan pengecekan residu setelah 6 minggu dari awal pemberian pakan.

5) T4 : Lobster diberi pakan berupa pellet dengan campuran Chloramphenicol dengan dosis $2 \mathrm{~g} / \mathrm{kg}$ pakan selama seminggu, setelah itu diberi pakan pellet tanpa campuran Chloramphenicol kemudian dilakukan pengecekan residu setelah 7 minggu dari awal pemberian pakan.

6) T5 : Lobster diberi pakan berupa pellet dengan campuran Chloramphenicol dengan dosis $2 \mathrm{~g} / \mathrm{kg}$ pakan selama seminggu, setelah itu diberi pakan pellet tanpa campuran Chloramphenicol kemudian dilakukan pengecekan residu setelah 8 minggu dari awal pemberian pakan.

\section{Persiapan Akuarium dan Ikan Sampel}

Akuarium yang akan digunakan di cuci dahulu menggunakan detergen kemudian di sterilisasi menggunakan chlorine dan dikeringkan sampai chlorine tidak berbau. Setelah kering, akuarium diisi air tawar kemudian diberi aerasi dan pipa-pipa kecil sebagai tempat persembunyian lobster.

Sampel yang digunakan diseleksi terlebih dahulu dan dilakukan aklimatisasi agar lobster dapat bertahan dari lingkungan yang berbeda dari sebelumnya. Lobster sebanyak 40 ekor yang memiliki ukuran antara 5-8 $\mathrm{cm}$ dipelihara dalam 8 buah akuarium dan diberi pakan berupa pellet yang dicampur dengan Chloramphenicol dan diukur residunya pada minggu ke-1, minggu ke-4, minggu ke-6, minggu ke-7 dan minggu ke-8 $( \pm$ delapan minggu).

\section{Pembuatan Pakan}

Pakan yang dipakai terdiri dari campuran satu kilogram pellet yang dicampur dengan Chloramphenicol sebanyak $2 \mathrm{~g} / \mathrm{kg}$ pakan dan progol sebanyak $5 \mathrm{~g} / \mathrm{kg}$ pakan kemudian dilarutkan dengan air secukupnya. Progol berbentuk serbuk dan memiliki fungsi sebagai perekat yang mempunyai daya rekat tinggi dan praktis penggunaannya. Campuran tersebut kemudian dijemur hingga kering dan siap.

\section{Pengecekan Jumlah Residu}

Pengecekan jumlah residu (jumlah residu yang terdapat dalam tubuh losbter setelah perlakuan) dilakukan pada minggu ke-1, minggu ke-5, minggu ke-6, minggu ke-7 dan minggu ke-8. Penetapan residu Chloramphenicol pada lobster dilakukan dengan menggunakan alat UPLC (Ultra performance liquid chromatografi).

Metode ini dilakukan dengan cara Mengambil $5 \mathrm{~g}$ daging lobster basah kemudian dipotong-potong dimasukkan ke dalam makro tube .Setelah itu ditambahkan $2 \mathrm{ml}$ aquabides, divortex selama satu menit kemudian didiamkan.Setelah se-puluh menit ditambahkan $6 \mathrm{ml}$ etil asetat lalu divortex selama satu menit. Setelah itu sampel disentrifusgasi selama lima menit dengan kecepatan $3500 \mathrm{rpm}$ dan diambil 4,2 $\mathrm{ml}$ lapisan organik (lapisan paling atas) menggunakan pipet dan dikeringkan pada suhu $30^{\circ} \mathrm{C}$ dengan menggunakan evaporator. Sampel (residu) disuspensikan dengan 1,4 ml hexana-klorofom, kemudian ditambahkan 0,7 $\mathrm{ml}$ air pro KCKT dan divortex selama 5 menit (low speed). Sampel disentrifugasi pada kecepatan 3500 rpm selama 10 menit, diambil supernatannya (lapisan bagian atas) dan diinjeksi supernatan ke alat KCKT (Gambar 1).

\section{Hasil Penelitian \\ Pemilihan Lobster Air Tawar}

Penelitian ini menggunakan Lobster Air Tawar atau yang biasa dikenal dengan sebutan lobster capit merah sebanyak 18 ekor. Lobster yang diambil 
Tabel 1. Rataan ANOVA Waktu Pengukuran Kadar Chloramphenicol pada Lobster Air Tawar

\begin{tabular}{cc}
\hline PERLAKUAN (WAKTU) & RESIDU CHLORAMPHENICOL $($ PPB) \\
\hline Kontrol & $0,558 \pm 0.370^{\mathrm{f}}$ \\
Minggu I & $31,962 \pm 1.818^{\mathrm{a}}$ \\
Minggu IV & $21,324 \pm 1.985^{\mathrm{b}}$ \\
Minggu VI & $10,852 \pm 0.643^{\mathrm{c}}$ \\
Minggu VII & $5,68 \pm 0.552^{\mathrm{d}}$ \\
Minggu VIII & $3,53 \pm 0.590^{\mathrm{e}}$ \\
\hline
\end{tabular}

Superskrip berbeda pada kolom yang sama menunjukkan perbedaan nyata $(\mathrm{p}<0,05)$.

Tabel 2. Hasil pengukuran kualitas air pada Lobster Air Tawar

\begin{tabular}{cc}
\hline PARAMETER & NILAI PENGUKURAN \\
\hline Suhu & $28{ }^{\circ} \mathrm{C}-30^{\circ} \mathrm{C}$ \\
Amoniak & $0 \mathrm{ppm}$ \\
pH & $7,5-8,0$ \\
DO (Dissolve Oxygen) & $6 \mathrm{ppm}$ \\
\hline
\end{tabular}

(b)
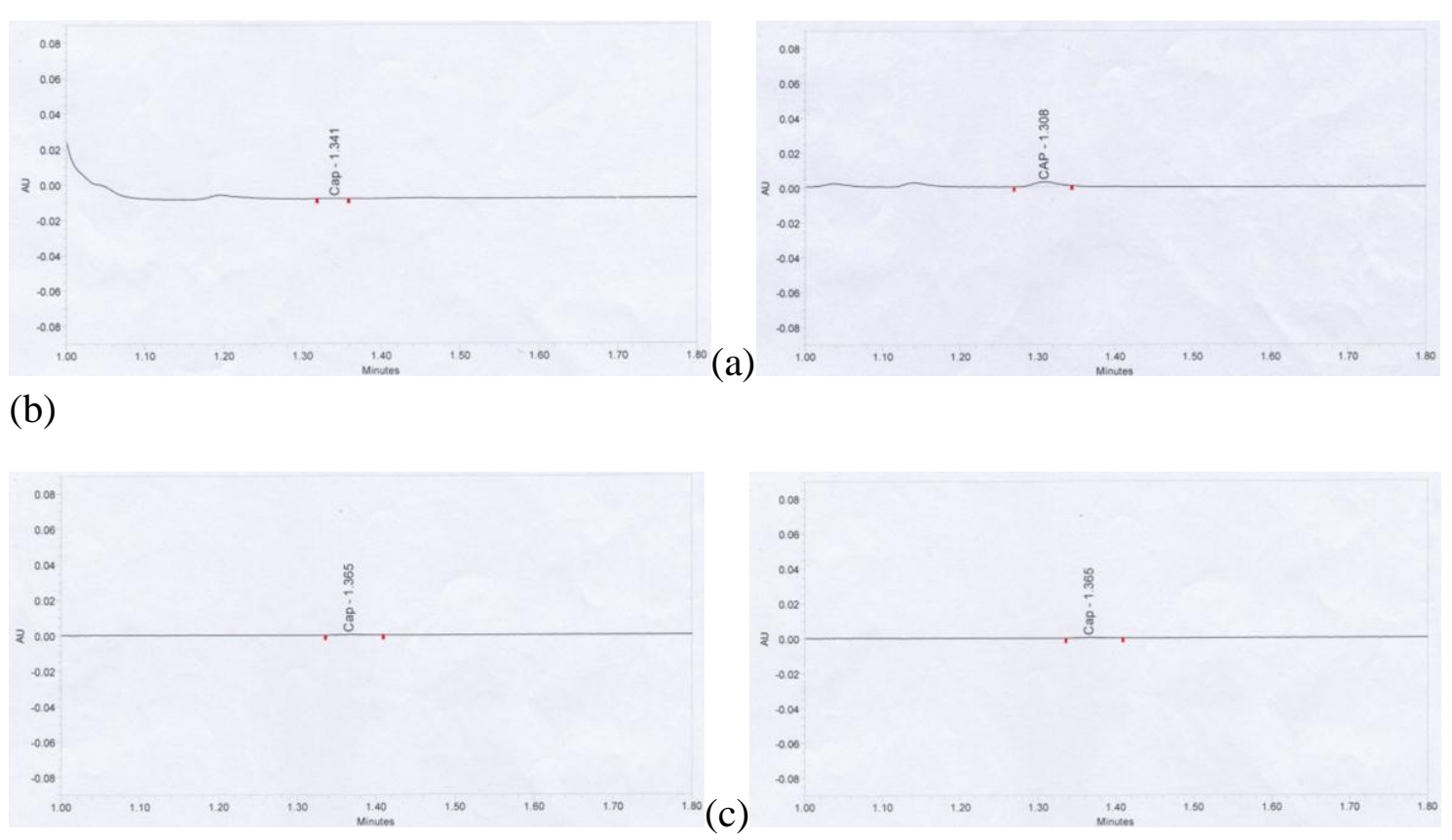

(d)

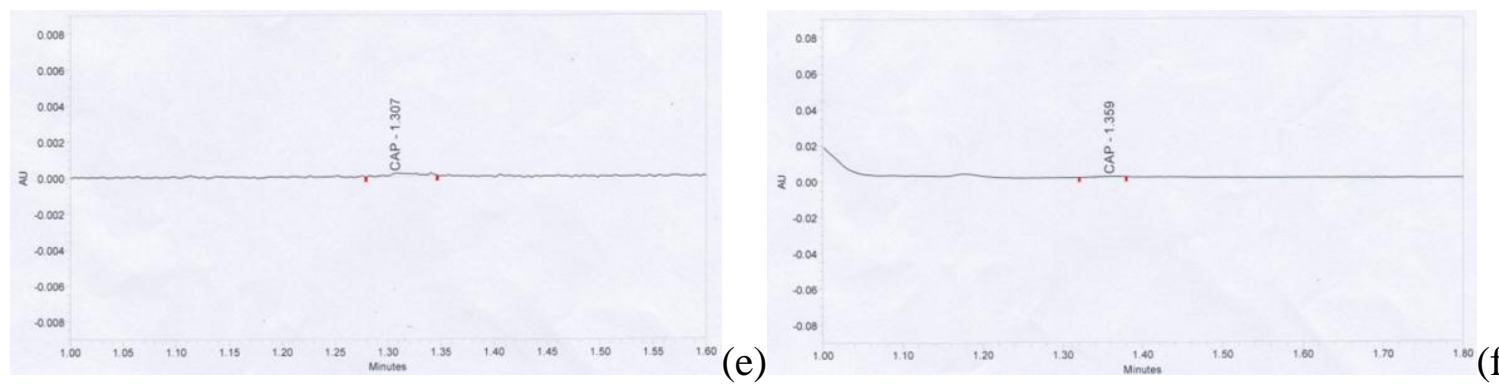

Gambar 1. Grafik Hasil Pengecekan Residu pada Alat UPLC. a) Sampel Kontrol, b) Sampel Minggu ke-I, c) Sampel Minggu ke-IV, d) Sampel Minggu ke-VI, e) Sampel Minggu VII, f) Sampel Minggu ke-VIII. 
berumur tiga bulan dengan rata-rata berat tubuh kurang lebih 28-35 gram. Lobster didapat dari Pasar Ikan Hias Gunung Sari Surabaya dengan pengambilan secara acak namun memenuhi kriteria yang layak digunakan sebagai obyek penelitian.

Kriteria yang dimaksud yaitu tubuh lobster berwarna biru gelap dengan sedikit warna merah pada kedua capitnya, memiliki capit lengkap, bergerak aktif, dan tidak terdapat luka disekitar tubuhnya.

\section{Kadar Chloramphenicol dalam Lobster Air Tawar}

Pada penelitian yang telah dilakukan pada bulan November 2013 sampai bulan Januari 2014 yang menggunakan alat Ultra performance liquid chromatografi (UPLC).

Hasil pengukuran residu

Chloramphenicol tertinggi terdapat pada perlakuan minggu pertama yaitu 31,962 ppb, pada perlakuan minggu keempat yaitu 21,324 ppb, pada perlakuan minggu keenam yaitu $10,852 \mathrm{ppb}$, pada perlakuan minggu ketujuh yaitu 5,68 ppb dan pada perlakuan minggu kedelapan yaitu 3,53 ppb. Hal ini menunjukkan adanya penurunan kadar Chloramphenicol pada minggu pertama hingga minggu kedelapan. Sedangkan pada kontrol kadar Chloramphenicol menunjukkan hasil yang rendah yaitu sebesar $0,558 \mathrm{ppb}$.

\section{Pengukuran Kualitas Air}

Lingkungan media pemeliharaan sangat berpengaruh terhadap lobster yang diteliti. Baik buruknya lingkungan media pemeliharaan akan menentukan keberhasilan dalam suatu penelitian. Kualitas air memegang peranan dalam budidaya lobster karena lobster mempunyai batas toleransi tertentu terhadap faktor lingkungan di mana organisme tersebut berada.

Chloramphenicol yang masih terkandung dalam air, jika tidak dilakukan penggantian air maka residunya akan tetap berada di dalam air dan terus dikonsumsi oleh lobster sehingga kadar residu dalam tubuh lobster tidak akan menurun. Selain itu kualitas air yang buruk akan mempengaruhi kesehatan tubuh lobster sehingga metabolisme lobster terganggu dan proses eliminasi residu akan berjalan lambat. Data kualitas air pemeliharaan lob-ster berlangsung dapat dilihat pada Tabel 2 .

\section{Pembahasan \\ Residu Chloramphenicol}

Chloramphenicol merupakan antibiotik yang bekerja dengan jalan menghambat sintesis protein bakteri. Bagian yang dihambat adalah enzim peptidil transferase yang berperan sebagai katalisator untuk ikatan-ikatan peptida pada proses sintesis protein bakteri. Apabila antibiotik tersebut diberikan dalam waktu yang lama, maka akan terjadi timbunan antibiotik di dalam tubuh yang disebut dengan residu.

Pada Tabel 1, hasil yang didapat yaitu kontrol memiliki kadar Chloramphenicol sebanyak 0,558 ppb. Dari hal diatas menunjukkan bahwa pembudidaya lobster menggunakan antibiotik Chloramphenicol selama proses budidaya dikarenakan pada sampel lobster terkandung Chloramphenicol. Pada waktu pengamatan awal terdapat perbedaan yang nyata pada setiap perlakuan. Pada rata-rata residu Chloramphenicol tertinggi terdapat pada perlakuan minggu pertama yaitu 31,962 ppb yang berbeda nyata dengan perlakuan minggu ke-4, minggu ke- 6 , minggu ke- 7 dan minggu ke-8. Rata-rata residu Chloramphenicol terendah ditemukan pada kontrol yaitu $0,558 \mathrm{ppb}$.

Selama seminggu pada awal perlakuan, lobster diberi pakan pelet yang dicampur dengan Chloramphenicol sebanyak $2 \mathrm{~g} / \mathrm{kg}$ pakan dan dilakukan pemeriksaan sehingga didapatkan kadar sebanyak 31,962 ppb. Akhir perlakuan, yaitu setelah delapan minggu Chloram-phenicol pada tubuh lobster menurun sehingga didapatkan hasil akhir sebanyak 3,53 ppb.

Penurunan residu Chloramphenicol pada tubuh Lobster Air Tawar pada minggu pertama hingga minggu ke dela- 
pan rata-rata sebesar 28,432 ppb. Hal ini dikarenakan pertumbuhan lobster berjalan dengan baik. Faktor-faktor yang berperan dalam pertumbuhan lobster antara lain pemberian pakan dan faktor lingkungan. Pemberian pakan sebanyak 5\% dari bobot tubuh lobster setiap harinya mampu memberikan pertumbuhan yang baik bagi lobster. Hal ini juga disebabkan pakan pellet yang diberikan memiliki bau yang khas, sehingga memudahkan lobster untuk mendeteksi pakan yang diberikan (Hakim, 2007)

Beberapa faktor lingkungan abiotik yang mempengaruhi pertumbuhan lobster adalah temperatur, kualitas air (terutama oksigen terlarut, kalsium dan $\mathrm{pH}$ ), tingkat gizi dan komposisi habitatnya (Aiken and Waddy, 1992). Faktor lingkungan yang mendukung, tentu akan memberikan dampak yang baik terhadap nafsu makan lobster. Meningkatnya nafsu makan merupakan salah satu ciri lobster yang sehat. Jika kondisi lobster dalam keadaan sehat maka akan mempercepat proses metabolisme senyawa dalam tubuh dan mempercepat proses eliminasi residu Chloramphenicol yang terdapat dalam tubuh. Eliminasi akan dilakukan oleh alatalat ekskresi, terutama ginjal, dalam bentuk kemih dan lewat usus dalam bentuk tinja (Rahayu, 2010).

Menurut penelitian sebelumnya terhadap jenis Crustacea (Nurhamida, 2012) bahwa udang galah yang diberi campuran Chloramphenicol dengan dosis $2 \mathrm{~g} / \mathrm{kg}$ pakan terdeteksi residu Chloramphenicol sebesar 7,71 ppm (7710 ppb) dan menurun menjadi sebesar 2,90 ppm (2900 ppb) setelah 30 hari masa perlakuan. Hal ini menunjukkan bahwa selama 30 hari, residu Chloramphenicol tereduksi sebanyak 4,81 ppm.

\section{Daftar Pustaka}

Adam, R. 2002. Veterinary Pharmacology and Therapeutics. IOWA State University Press/Ames. USA.
Aiken, D.E., Waddy, S.L., 1992. The growth Process in Crayfish. Rev. Aquat. Sci. 6.

Akhmadi, Y. N. 2006. Aplikasi Bagan Kendali Proses Berdasarkan Tingkat Residu Chloramphenicol Pada Daging Rajungan Di PT. Mina Global Mandiri Purwakarta. Skripsi. Fakultas Teknologi Pertanian. Institut Pertanian Bogor. Bogor.

Boyd, C. E. 1982. Water Quality Management for Pond Fish Culture. Amsterdam: Elsevier Scientific Publishing Company.

Hakim, R. R. 2008. Addition of Calcium with Different Dose to Success of Red Claw (Cherax quadricarinatus) Gastrolisation. Proceeding of International Research Seminar and Exhibition. Research Center of UMM. Malang.

Lukito, A. dan P. Surip. 2007, Panduan Lengkap Lobster Air Tawar. Penebar Swadaya. Jakarta.

Nurhamida, L. 2012. Lama Waktu Henti Obat (Withdrawl Time) Chloramphenicol Pada Udang Galah (Macrobrachium rosen-bergii). Fakultas Perikanan dan Kelautan Universitas Airlangga. Surabaya.

Rouse, D.B.,1997. Production of $\mathrm{Au}-$ stralian Red Claw Crayfish. Auburn University. Alabama. USA.

Satyani, D. 2003. Pengaruh Umur Induk Ikan Cupang (Betta splenden Regan) dan Jenis Pakan terhadap Fekunditas dan Produksi Larvanya. Jurnal Penelitian Perikanan Indonesia.

Tendencia, E.A dan de La Pena L.D. 2001. Antibiotic Resistance of Bacteria from Shrimp ponds. Aquaculture 195:19 